\title{
O TEATRO AMBIENTAL E A INVASÃO DO RECREIO
}

\section{Gabriela Greco}

Recebido em 25/06/2017

Aprovado em 28/07/2017 
Neste artigo descreverei de forma detalhada as práticas e estratégias realizadas com as/os alunas/os do grupo de teatro nos momentos de recreio no pátio da E.M.E.F. Mário Quintana, uma escola da periferia de Porto Alegre. Os processos criativos teatrais ocorreram na tentativa de problematizar a tensão existente entre os elementos do real e da ficção, que perpassam a cena contemporânea atual. Discute-se os conceitos de teatro ambiental e teatro de invasão, a partir dos estudos dos autores Richard Schechner e André Carreira. Estes procedimentos fizeram parte de minha dissertação de mestrado no Programa de Mestrado Profissional em Artes da UDESC. As propostas de investigação foram realizadas por crianças e adolescentes em 2015 e concluídas no ano 2016. Este artigo traz como sujeitos as/os alunas/os do grupo mencionado, e a comunidade escolar que, por meio de entrevistas e depoimentos, ocupam um lugar de fala e apontam para a relevância do trabalho de investigação teatral realizado na escola pública.

Palavras-Chave: Teatro na escola. Teatro Ambiental. Teatro de Invasão.

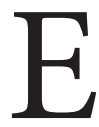

sta é uma proposta de investigação artística com um grupo de teatro, que teve como foco a criação de estratégias que interferiram no ambiente escolar e apontaram para outros caminhos não percorridos.

As ações criadas visaram romper com algumas das estruturas dramáticas já conhecidas pelas/os componentes do grupo de teatro da escola, tais como a presença de um personagem fictício e a representação de narrativas dramáticas lineares. Com isso, propus procedimentos que as/os encorajaram a se expor e se arriscar em novas linguagens cênicas por meio de outras aprendizagens, como as intervenções no pátio, estratégias de ações poéticas que ocorreram na escola durante os momentos do recreio.

O resultado dessas práticas sucedeu uma análise, por meio de entrevistas e depoimentos coletados por mim, sobre o impacto que as estratégias causaram sobre os sujeitos envolvidos: alunas/os, familiares e comunidade escolar.

Estratégia 1: Exercício de deslocamento pelo espaço em forma de linha. Os componentes do coro, posicionados um ao lado do outro, deslocam-se para frente, juntos, até um determinado ponto, e retornam para o ponto inicial. Qualquer um, a qualquer momento, pode parar, desprender-se do grupo, e neste lugar permanecer até que o coro retorne. Então, ao passar, o componente pode integrar-se de volta à caminhada.

O exercício é realizado com modulação de velocidade - do um ao dez, (slow motion) até a corrida - durante o recreio, que tem duração de vinte minutos. A plateia prontamente se formava para assistir. Algumas crianças sentaram-se ao chão, organizadas de frente para o coro, conforme vemos nas imagens a seguir: 

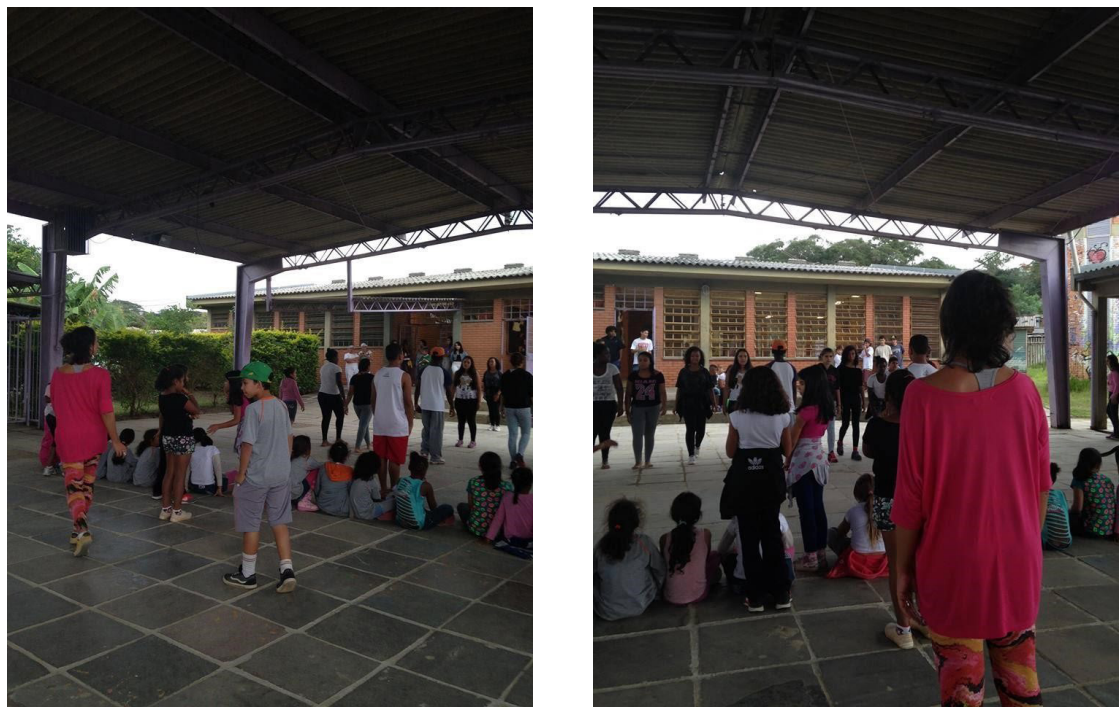

Figura 1 - Exercício de deslocamento em coro. Fotografias de Solange Roland.

É importante ressaltar que em nenhum momento foi anunciado o procedimento. Nós invadimos o espaço, chegamos juntos. Eu carregava a caixa de som, enquanto as/os alunas/os se posicionavam no meio da área coberta do pátio. A música alta dava início à ação. Do mesmo modo, em nenhum momento foi dito à "plateia" onde deveriam ou poderiam ficar. Instalaram-se e, do mesmo modo, ocuparam o espaço.

A ruptura que nossa ação propôs abriu alternativas que não tínhamos considerado. $\mathrm{O}$ inesperado do acontecimento em meio ao momento do recreio pode ser compreendido conforme o que Carreira (2009) sugere sobre o teatro de invasão:

São as regras do ambiente que se fazem mais explícitas e condicionam o trabalho dos atores, ou o teatro com toda a sua potência de significação e os atores com sua capacidade lúdica serão os vetores que alterarão o repertório de usos? [...] A invasão cênica é um gesto que se politiza por que representa uma ocupação objetiva de um espaço definido por um repertório de usos cotidianos, no qual o teatro não pertence naturalmente (CARREIRA,2009,p.3).

Carreira (2009) se refere ao repertório de usos do espaço da rua, que nesta pesquisa transponho para o ambiente aberto da escola, em que há o encontro entre os que atuam e os que se colocam no lugar dos que assistem. Arrisco afirmar que o jogo se configura e se estabelece justamente nessa relação entre atores que jogam e público que também 
joga, daquela linha imaginária e invisível que une os olhares, desfazendo territórios tanto no olhar de quem faz como no olhar de quem vê.

Carreira (2009), em suas investigações, se refere à cidade, silhueta da cidade, invasão da cidade, repertório de usos da cidade; eu aqui peço emprestado os conceitos para pensar o fluxo da escola, a silhueta da escola, a invasão do pátio, mesmo que o pátio não seja a rua, pois o pátio de uma escola ainda é permeado por regras necessárias para o convívio de tantas crianças e jovens que ocupam o mesmo espaço. $\mathrm{O}$ autor defende a ideia de uma dramaturgia que opera dialogando com o acontecimento cênico, o que intensifica a teatralidade já aparente no cotidiano da rua, mesmo que por vezes num diálogo nada amistoso, o que vai gerar a noção de um teatro de invasão. Na rua o passante/habitante/transeunte/cidadão nada mais é do que fabricante/produtor de teatralidade.

Estes fluxos de deslocamento, de certa forma, recortam uma silhueta do cotidiano repetitivo da escola, como a ida ao refeitório para o lanche, as idas ao banheiro, a fila no bebedouro, a disputa pelas quadras, balanços e árvores, a disputa pela bola, pela atenção, os encontros em recantos não visados para compartilhar balas e refrigerantes. Tudo muito rápido, pois são apenas vinte minutos de intervalo.

Do mesmo modo, há fluxo de circulação de professores que saem rapidamente de dentro dos prédios e cruzam o pátio para a ida ao banheiro, enquanto funcionários e demais colegas da equipe diretiva circulam como patrulha para evitar conflitos e possíveis acidentes. Todos estes movimentos podem ser aproximados aos fluxos das pessoas que se movimentam pela cidade de forma também acelerada e objetiva, e que são interpeladas por uma invasão ou intervenção teatral.

Esta invasão a que nos propomos, eu e as/os alunas/os, surgiu como forma de abrir fendas e frestas no imaginário dos demais alunos que estão distraídos com seu momento aparentemente mais livre. Livres das salas fechadas, com os corpos aprisionados em cadeiras e mesas; livres por vinte minutos e, portanto, em um momento propício, em princípio, para receber algo para ver.

Estratégia 2: Criação de coreografias com tonéis de madeira e com panos coloridos. Em dois grupos os alunos e as alunas exploraram o objeto e criaram sequências coreográficas diferentes. Propus algumas ações para melhor manipulação destes objetos e alguns deslocamentos e desenhos no espaço, que contribuíram para que todos formassem, em alguns momentos, um coro único, conforme as imagens a seguir: 


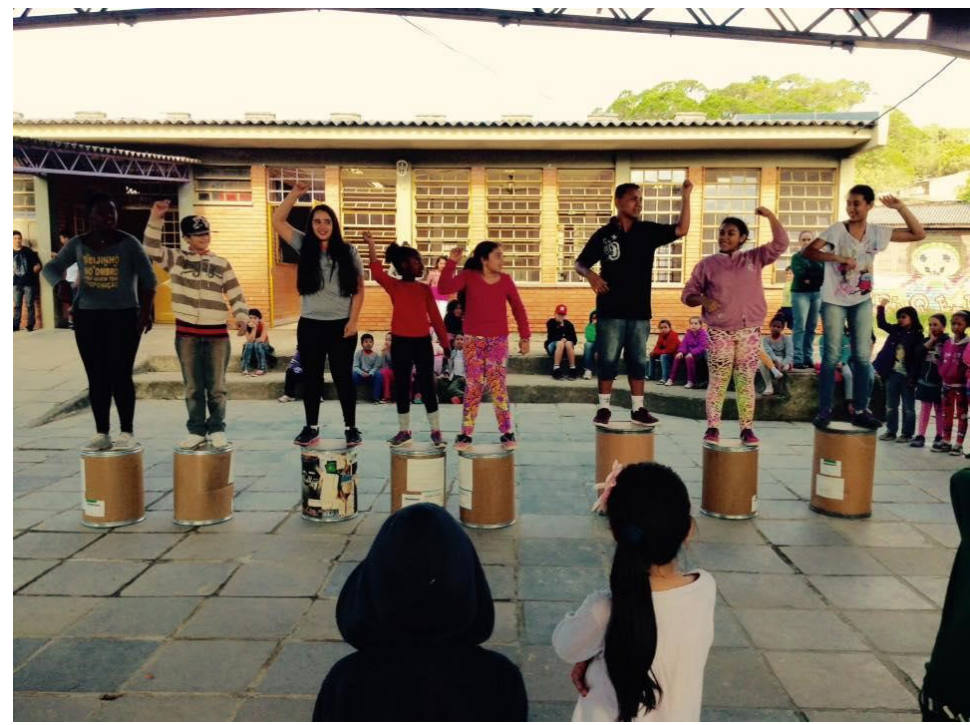

Figura 2 - Coreografias com o uso dos tonéis. Fotografias de Andrea Ayres.
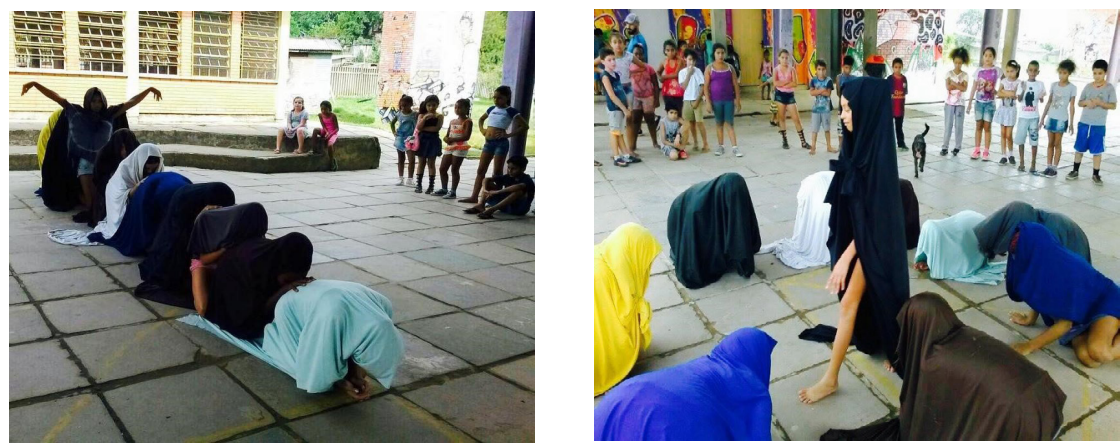

Figura 3 - Coreografia com o uso de panos. Fotografias de Andrea Ayres.

A invasão, desta vez, além de sonora, era também visual, pois os tonéis - assim como os panos e a visualidade criada - chamavam a atenção e já revelavam, por sua simples presença, que algo iria acontecer. Neste momento, alguns alunos não-atores já haviam percebido que nas quartas-feiras à tarde coisas aconteciam no pátio, por isso prontamente já se organizavam em torno do grupo. 
Tanto com os tonéis como com os panos o grupo estava dividido em dois. As ações e movimentos eram diferentes, gerando multifocos, mas isso não foi suficiente para desviar o olhar do público, e sim considerado foco único, já que acontecia no mesmo perímetro do ambiente da área coberta. Schechner (1968) explica por que:

Um foco único é a marca registrada do teatro tradicional. Mesmo quando as ações acontecem simultaneamente e estão espalhadas ao longo de um grande palco. [...] O teatro ambiental não elimina essa prática. É útil. Mas adiciona outros dois tipos de foco, ou de falta de foco. No multifoco, mais de um evento - alguns do mesmo tipo, ou de mistura de mídias - acontecem ao mesmo tempo distribuídos por todo o espaço. Cada evento particular concorre com os outros pela atenção da audiência. O espaço é organizado de forma que nenhum espectador possa enxergar tudo. $\mathrm{O}$ espectador deve se deslocar ou mudar seu foco de atenção para pegar tudo o que está acontecendo (SCHECHNER, 1968, p. 126).

Como podemos observar, neste trecho o autor aponta para uma marca registrada do teatro tradicional. Sabemos hoje que, como estas, existem várias outras marcas, e não se trata de eliminarmos estas práticas, mas sim transformá-las de forma a ser possível continuarmos a fazer pesquisa em teatro na escola, bem como surpreender uma audiência pouco acostumada com outras narrativas que não sejam as lineares e unifocais.

Nesta ação com os tonéis ainda não havia deslocamento do público e o foco tinha tendência a se manter no mesmo ambiente, com pouca interação entre atores e público. Já na prática que veremos a seguir, a relação entre o que era feito e o que era visto e entre quem agia e quem olhava, se alterou.

É preciso ressaltar que estas estratégias foram geradas a partir de uma necessidade minha de ampliar a visibilidade do grupo de teatro na escola, de me deslocar e me colocar em risco, bem como desacomodar o trabalho para proporcionar novas aprendizagens a todos. Estas práticas não podem ser consideradas exemplos modelares pedagógicos e didáticos a serem copiados por professores em sala de aula, mas considero que esta experiência aponta para possibilidades de se explorar os diversos ambientes da escola, que não foi estruturada para receber o teatro em suas instalações. Desse modo, precisamos encontrar meios para que o teatro habite este lugar.

Estratégia 3: Criação de Corpos-Manequins. A ideia surgiu para mim como uma reflexão a partir do pensamento de Fredric Jameson. O autor, ao propor uma ideia de "esmaecimento dos afetos", me remete à imagem do enrijecimento da alma e do corpo. Propus uma conversa com os alunos sobre excesso de consumo, a massificação e o tempo de 
não-viver, sobre corpos sem alma, sem vida e sem energia. Iniciamos uma série de exercícios de manipulação física, movimento com as articulações e jogos de improvisação para transformarem-se em robôs e bonecos dentro de caixas, que eram ligados e desligados pelas crianças, seus donos.

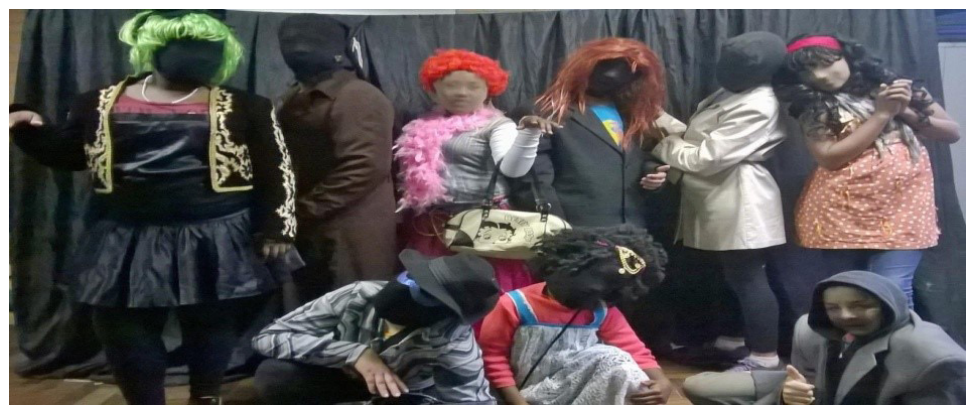

Composição de figuras/corpos/manequins. Fotografias de Andrea Ayres.

A utilização da meia-calça preta como máscara surge como uma estratégia para compor o coro. Esta ideia foi inspirada em uma experiência que tive com um dos métodos utilizados por Ariane Mnouchkine com os atores do Théâtre du Soleil. Em uma oficina com Andreas Simas e, posteriormente, em contato com Serge Nicolai ${ }^{1}$, fizemos alguns exercícios com as meias pretas ajustadas ao rosto para jogar como coro e também usadas para a manipulação de marionetes-humanos.

Apresento este processo, mais detalhado no último capítulo, para ilustrar como algumas experiências como atriz podem ser transpostas para a escola de forma a compartilhar técnicas, processos e criações, e que podem ser experimentadas com os alunos.

Estratégia 4: Outro desdobramento deste processo com as máscaras e as figuras criadas foi a invasão do recreio, em um cortejo criado pelo grupo, que consistia em transitar por todo o pátio da escola, em diferentes ambientes e, em cada um deles, realizar uma ação.

Tanto o trajeto como a ação realizada em cada ambiente foram inventados pelo grupo. Temos o depoimento da aluna Amanda, que reflete sobre como ela se sentiu e como foi a experiência de se expor utilizando a máscara negra.

1 Ator do Companhia francesa Thèatrê Du Soleil. Ministrou oficina em Porto Alegre, em 2012, que fez parte do projeto Conexão em Cena, criado pelo $19^{\circ}$ Porto Alegre em Cena para homenagear o centenário de nascimento de Nelson Rodrigues. Este projeto gerou o espetáculo Os Plagiários: Uma adulteração ficcional sobre Nelson Rodrigues, sob direção de Jezebel De Carli, Marcelo Restori, Guadalupe Casal e Mário de Ballentti. 


\section{Depoimento Amanda:}

Hoje foi legal, tava todo mundo tentando me achar, procurando por mim, eu louca para dizer "eu tô aqui!", mas eu pensava "não fala, não fala, não fala". Foi legal as crianças nos acompanhando, né. Eu ouvia elas dizendo "é um palhaço. Não, esse daqui é um monstro", isso e aquilo outro. Eu fiquei meio ruborizada, meio tímida, na hora dá um frio na barriga.

O que tu acha que vocês eram? Ou o que vocês poderiam ser, que figuras eram aquelas?

Acho que era figuras tipo personagens.

Tu achas que vocês eram personagens?

Eu acho que eram só figurinos, na verdade mas eu to falando personagens, tipo assim, além de ser figurinos, a gente tentou se colocar no personagem assim, eu tô falando de mim, não sei como foi para os meus colegas, mas eu tava tentando entrar dentro do personagem, porque quando a gente vai pro recreio, a gente tira um pouco da concentração e sempre olha para um lado e para o outro, mas até que a máscara tava ajudando bastante. Eu gostei, eles saem falando sobre a gente.

Neste relato podemos perceber que a aluna acredita que tanto a máscara quanto o "vestir" um personagem auxiliam na concentração e proporcionam uma sensação de segurança e proteção do outro. A tendência do aluno iniciante é estar mais fora do que dentro da cena. Existe uma preocupação com o julgamento do outro, com o olhar que vem do outro, com as risadas. Auxiliar na desconstrução deste medo do olhar do outro é uma tarefa muito difícil, um trabalho árduo, que exige paciência, escuta, respeito e delicadeza.

Por isso, é muito importante que o professor de teatro esteja atento, para não ultrapassar estes limites dos alunos. Muitas vezes a pressão na escola e a necessidade de ver algo acontecer logo, de obter resultados produtivos, podem ser um verdadeiro "tiro no pé" e gerar o efeito contrário. Nesta relação, tanto alunos como nós professores precisamos buscar a cumplicidade e a confiança necessária para que o trabalho de cena, tanto no processo como na exposição deste, seja prazeroso e saudável.

\section{Depoimento de uma criança que assistiu a invasão no recreio:}

Eu achei legal, achei divertido. A hora que eles subiram na árvore e eles começaram a contar, passaram por toda a escola, eu acompanhei eles porque eu queria ver tudo, eles usavam umas roupas estranhas e não dava para ver o rosto deles, achei sensacional. 
Aqui podemos observar o estranhamento gerado por um simples caminhar, ocupar ambientes, estar com roupas estranhas e assumir outra presença corporal. Romper com este fluxo cotidiano do recreio, surpreender e tomar de assalto, como diz Carreira (2009), foi o objetivo destas estratégias, bem como gerar perguntas, curiosidades, dar a ver, fazer pensar sobre o porquê eles estavam ali e o que eles estavam fazendo, não para interromper o recreio, tão pouco para tirar o momento livre da gurizada, mas para colorir, poetizar, abrir espaços, chamar para o jogo, para a brincadeira, conduzir para outro lugar.

Carreira (2011) propõe de forma provocadora a ideia de um "ator invasor". Aqui eu pensaria em um "aluno-ator-invasor". Esclarece o autor: "A presença deste ator invasor é o ponto inicial da transformação da rotina. O reconhecimento de sua condição extracotidiana é um elemento fundamental para a abertura de um espaço lúdico que estimule todo tipo de participação dos espectadores." (CARREIRA, 2011, p. 20).

Busco transpor as ideias do autor, que trata de um teatro de invasão na rua, para uma ideia de invasão dos ambientes abertos e de convívio público da escola, ou seja, o recreio. Esta transformação da rotina existente na rua e pode ser observada, salvo as devidas proporções, na rotina da escola. A transformação da rotina era também uma provocação que eu fazia ao grupo, pois este era surpreendido a partir de algumas propostas relâmpago que eu fazia, algumas vezes sem avisá-los e sem articular a invasão previamente.

\section{Depoimento Bianca:}

$\mathrm{Eu}$ às vezes, tenho vergonha de fazer peça, e na rua não sei o que é que me deu em mim, eu não tive vergonha nenhuma. As pessoas acompanhavam a gente, aiiiii muito legal.

O depoimento de Bianca nos mostra como o caráter despretensioso da ação de invasão trouxe para a aluna uma tranquilidade para brincar, errar e se atrapalhar.

Ao longo dos estudos me deparei com alguns capítulos da obra "Pós-Modernismo: a lógica cultural do capitalismo tardio", de Fredric Jameson (2007). Fui tocada profundamente pela ideia que o autor traz sobre o colapso do indivíduo provocado pelo capitalismo. Associei este pensamento à imagem da máquina que colapsa e, desta forma, pensava em um corpo-máquina que falha por excesso de esforço ou funcionamento.

Resolvi experimentar isso com as/os alunas/os: brincar de ser máquina. Criamos estes Corpos-manequins: corpos que foram criados como uma variação do jogo de manipulação de marionetes. Durante a experi- 
mentação deste jogo com fios imaginários, eu solicitava às/aos alunas/ alunos que pesquisassem movimentos possíveis e pequenas ações que um boneco/robô/máquina pudesse realizar. Conforme eu conduzia o processo elas/eles respondiam de forma atenta e concentrada. Nas indicações senti necessidade de dizer frases provocativas do tipo: lembre-se que este corpo não tem vida! Como é me mover como um robô? Que ações meu corpo pode fazer? Como é este corpo? Como ele olha? Como ele age? São perguntas que foram surgindo à medida que eu observava o trabalho de investigação deste corpo.

Imaginei que estes bonecos poderiam ser propriedade de uma criança muito mimada, furiosa e agressiva e que gostava de destruir os brinquedos. Ela joga o/a boneco/boneca de um lado para o outro. Como é este corpo que falha? Como é este boneco quando quebra? Como ele vai se estragando? É interessante ver que os corpos se aceleravam conforme eram estimulados pela música de Tom $Z^{2}{ }^{2}$, e no momento final eu conduzi para que todas/todos caíssem ao chão.

No decorrer da descrição desta prática percebo o quanto se torna necessário analisar e refletir sobre como os corpos podem ser manipulados, por mim, professora, por nós, professores.

Trago de novo para a reflexão as contribuições da arte-educadora Carminda Mendes André (2013), que de forma muito lúcida alerta sobre o teatro na escola e a fabricação estratégica de corpos, baseada nos estudos de Foucault:

A estrutura do drama e a encenação moderna, ambos inseridos na escola por meio do teatro dramático, tornam-se instrumentos pedagógicos para a disciplinarização dos corpos e das mentes. Como tecnologia para certa ortopedia psíquica, o teatro assim utilizado torna-se saber-poder (ANDRÉ, 2013, p. 71).

A pesquisadora fala, entre tantas coisas, sobre as "práticas fora da lei”. Ela acredita que alguns educadores, inclusive arte-educadores, podem contribuir para uma ideia de disciplina autoritária e fazer a manutenção do jogo de poder. André (2013) problematiza o drama na escola e faz uma crítica sobre uma dramaturgia que tem uma verdade a ser defendida, pois não há mais uma verdade, mas muitas, assim como não é possível a unificação de vozes e o desejo de convencer o outro desta verdade.

Podemos aqui acordar que enquanto arte-educadores precisamos descobrir formas de orquestrar esta polifonia de vozes e estas realidades diversas e encontrar caminhos para práticas fora da lei, em busca de uma 
emancipação de si e do outro. Não sei se os caminhos que percorro nesta pesquisa estão nesta direção, mas é por esta rota que pretendi transitar.

O procedimento de preparação do trajeto para esta invasão que chamamos de Aliens Colors ocorreu uma hora antes do recreio. O grupo voltou para a sala de ensaio e, depois de organizar as ações e a rota que iria percorrer, selecionou os figurinos e objetos e invadiu o recreio conforme combinado.

Fiz um registro em vídeo da ação e procurei não conduzir nem interferir em nada que acontecesse, salvo alguma situação que pudesse colocar algum/alguma aluno/aluna em risco físico ou emocional. Para a nossa surpresa, desde o momento em que saímos da sala até o retorno, quinze minutos depois, houve intensa participação das crianças que estavam no pátio. O grupo foi seguido e acompanhado o tempo todo e, no decorrer das trajetórias, muitos dos alunos interagiram ao imitar as ações, e assim fizeram parte do evento. O interessante foi observar que as/os alunas/alunos do grupo em nenhum momento se incomodaram ou solicitaram que eu intervisse na ocupação conjunta pelo "público" destes ambientes. A seguir, o depoimento da vice-diretora da escola, que fazia o acompanhamento do recreio conforme costume e observou atenta toda a movimentação:

Vice-diretora: Olha a galerinha toda atrás.

EU: O que que tu disse que aconteceu ali? (ela não lembra, fica pensando. Pergunto de novo: Como que tu viu essa coisa? O que aconteceu com as crianças no recreio?

Vice-diretora: Interagindo, tu diz?

EU: Não sei, estou te perguntando.

Vice-diretora: Eu acho que é um pouco de tudo assim, tem uma magia, tem uma coisa de eu me achar ali, me ver ali de alguma forma, sabe?

EU: Por isso tu acha que as crianças foram atrás?

Vice-diretora: É...é... é que eu não sei se é isso que acontece com elas, é assim como eu sinto de eu estar, de eu ver algo assim que não tem... que poderia ser eu ali, e eu não me mostro e ao mesmo tempo eu me mostro com o colorido. Eu consegui me expor anonimamente, sabe?

É muito interessante esta percepção da vice-diretora, que aponta, ao final de sua impressão, sobre o que viu naquela tarde. Trata-se de uma reflexão muito próxima das questões que venho tentando trazer aqui, ou seja, para ela, a criança que atua se esconde e se mostra ao mesmo tempo, e as demais que interagiram de alguma forma se viam naquelas que atuavam, por isso o desejo de alguns de fazer junto. O colorido mostra e a máscara esconde.

Quando ela relaciona o lugar de pertencimento por meio do "eu me achar ali, me ver ali de alguma forma" recordo de um dos trechos de Carreira (2011) ao se referir ao teatro de invasão na rua, que muito bem 
afirma esta relação dos atores com o espaço e deste com a audiência em um ambiente permeado de regras que são rompidas para que se dê o espaço para o lúdico.

Reitero que, embora o recreio, o pátio de uma escola não seja a rua, procurei traçar um paralelo entre alguns conceitos possíveis de se transpor para a cena no ambiente escolar.

Carreira (2009) diz que:

O gesto "inútil" dilata o papel do teatro de rua como fala de ruptura, assim, o lúdico termina por ser um elemento fundamental na desconstrução dos projetos (urbanos) bem como na modulação das hegemonias dos ambientes. O lúdico introduz tensões próprias e solicita percepções que deslocam o cidadão do seu lugar cotidiano [...] é a definição dos percursos que estabelece a identificação de referências tais como os limites e as zonas, e consequentemente ajudam a definir os territórios de pertencimento (CARREIRA, 2009, p. 7).

Nesse sentido, aqui podemos analisar o gesto inútil, como a própria palavra define, como aquilo que não serve, que não tem utilidade, porque não está para servir nem a serviço de nada, isto é, não trata de produzir mercadorias, apenas a experiência artística em si, com todas as suas repercussões. A simples presença do teatro, ou algo que se pareça com o que quer que chamemos hoje de teatro, em um ambiente que, para alguns desavisados, não lhes pertence, pode causar incômodo, ruído ou riso. Carreira (2009) fala sobre este deslocamento, daquilo que é da natureza, do cotidiano, sobre invadir para provocar e, de alguma forma, romper com o tempo e o espaço.

Quando a vice-diretora fala em "magia", ela parece estar se referindo ao estado lúdico que a ação proporciona, pois, segundo sua própria narrativa, ela foi tomada por aquele evento e levada para outro lugar, enquanto ali estava para vigiar e conter as crianças. Do mesmo modo, isso aconteceu com as crianças que necessitavam estar junto, fazer parte do ato, se misturar com a poesia presente naquelas figuras mascaradas e coloridas. Esta reação foi uma surpresa para mim e para as/os componentes do grupo. Nós também fomos tomados de assalto.

Com relação a essa troca entre atores e público nessa nova configuração, Schechner (1968) ressalta:

Uma vezabandonados os assentos fixos e a bipartição do espaço, possibilitamse relações totalmente novas. Pode acontecer um contato corporal entre performers e audiência de forma natural; os níveis da voz e as intensidades da atuação podem variar amplamente; pode se gerar uma sensação de experiência compartilhada [...] a ação respira e a própria audiência se torna um elemento cênico de grande importância (SCHECHNER, 1968, p. 111). 
É fundamental a afirmação do autor sobre a importância cênica da audiência na medida em que a ruptura com o habitual provoca novas formas de relações entre os que fazem e os que assistem, mas que também passam a agir. Antes destas experimentações no pátio durante o recreio, as/ os alunas/alunos do grupo demonstravam certo receio com o olhar e um possível julgamento que vem de fora, ou seja, da reação hostil deste público formado também por alunos, seus pares.

À medida que o trabalho se fortalece no ato do acontecimento, na continuidade da experimentação despretensiosa e na manutenção da ação poética com um caráter de exercício e ensaio, as relações se estreitam, o medo do desconhecido se desfaz e nesta aproximação entre aquele que faz para o outro e aquele que olha para o outro, se modificam, tanto as pessoas como as relações. As/os próprias/próprios alunas/alunos do grupo nos contam como foi essa experiência compartilhada, conforme trechos selecionados abaixo:

\section{Depoimento Débora:}

Hoje fizemos uma experiência de ir pra rua. As crianças estavam em volta. Primeiro dava um nervosismo e depois a gente até se diverte. Eles interagiam com a gente, com o que a gente fazia, quando a gente pulava, quando a gente andava. A gente fez alguns movimentos, quando a gente contava, eles paravam, dava um silêncio. Eles queriam saber o que ia acontecer, mesmo sabendo muitas vezes que não ia acontecer nada: mas eles estavam ali, porque é diferente, porque eles não veem isso todo dia, eles têm curiosidade.

EU - Tá, mas me explica, quando vem grupos de teatro se apresentar lá no pátio não é a mesma coisa? É uma coisa diferente que quase nunca acontece também.

- Sim, mas a gente sempre se apresenta aqui dentro, nunca é para todos. EU - E Por quê?

- Ah, porque alguns têm vergonha, outros já não querem porque vai pagar vale, é sempre o mesmo motivo, fazem teatro não querendo aparecer, sempre para as paredes.

EU-E por que vocês foram mascarados para o pátio?

-Não era para esconder a identidade, era meio que para chamar a atenção, para eles nos verem sem nos verem. A gente quer estar ali, mesmo que seja só caminhando, a gente quer se divertir, a gente quer aprender, a gente quer viver.

\section{Depoimento Eduardo:}

Hoje nós fizemos um trabalho que eu nunca fiz, foi a primeira vez que fiz esse trabalho. A gente se caracterizou na sala e saimos a fazer uma atividade para nós mesmos, mas aí o legal foi que as crianças do pátio participaram. Quando a gente deu volta, todo mundo foi junto com a gente para ver o que estava acontecendo, tipo um carnaval assim, sabe, passa as pessoas na rua e vai todo mundo atrás para se divertir. As crianças gostaram, eu também gostei, foi uma experiência nova pra mim, espero poder fazer outras vezes isso. 
Nestes depoimentos podemos verificar o prazer e uma certa satisfação ao afirmar que "eles gostavam". O artista faz sua arte, ou deveria fazer, em meu ponto de vista, a partir dos desejos daquilo que pretende dizer, expressar, denunciar e compartilhar, mas sempre com um olhar voltado para a crítica e reflexão sobre a vida, a humanidade e o mundo em que vivemos. O fantasma do olhar do outro sobre o seu próprio trabalho deixa de amedrontar a partir da maturidade e da compreensão de que por mais altruísta que seja o artista, ele jamais terá o controle sobre o gosto e a crítica do outro. Esta reflexão procuro fazer com as/os alunas/alunos, para que saibam lidar com este olhar crítico que vai e que volta. Além das impressões e surpresas sobre a reação da audiência, as/os alunas/alunos verificam a ausência de algo para ver, verificam o quanto qualquer movimento mínimo de dança, música, poesia, arte ou atuação desperta curiosidade.

O que me parece ao analisar este relato é que ele cumpre a função de despertar para o potencial da arte enquanto experiência, contribuindo para a transformação de um ser mais coletivo, que na sua própria diversão reflete sobre a reação do olhar do outro em experiência e intensidade também com o outro.

Giorgio Agamben (2005), ao tratar sobre a miséria das experiências, consegue ser ainda mais fatalista sobre o comportamento humano contemporâneo:

Pois o dia a dia do homem contemporâneo não contém quase nada que seja ainda traduzível em experiência [...] o homem moderno volta pra casa à noitinha extenuado por uma mixórdia de eventos - divertidos ou maçantes, banais ou insólitos, agradáveis ou atrozes - entretanto nenhum deles se tornou experiência. É esta incapacidade de traduzir-se em experiência que torna hoje insuportável - como em momento algum no passado - a existência cotidiana (AGAMBEN, 2005, p. 21).

Não há como não considerar impactante esta definição da vida contemporânea. E de forma muito crua o autor me faz pensar sobre o momento atual que vivemos. Auxilia-me inclusive a repactuar comigo mesma as escolhas que fiz e a compreender de onde vem tanta inquietação com a educação e com o teatro na escola.

$\mathrm{O}$ que percebo nos relatos das/os alunas/alunos sobre suas vidas e sobre o motivo que as/os levam à escola, no turno inverso, para fazer teatro, além do fato de "ser divertido" é porque:" não tem nada para fazer". Estamos agora falando em ocupar o tempo, as horas, quatro horas da vida. O teatro ocupa além do espaço, o tempo. Este tempo que pode ser suspenso, alterado e modificado: "por conseguinte, a tarefa original de uma autêntica revolução não é jamais simplesmente mudar o mundo, mas também, e antes de mais nada, mudar o tempo" (AGAMBEN, 2005, p. 109). 
Uma das propostas de alteração desta noção do tempo na ação realizada no pátio foi a do movimento em câmera lenta ou slow motion, experienciado no recreio, por exemplo. Isto conduziu o grupo a uma resistência do corpo no espaço. Foi necessário muito mais atenção e muito mais equilíbrio para agir em slow motion. Foi necessário driblar a ansiedade, a aceleração e a sensação de que não se fazia nada.

Estar parado e estar agindo com micro-ações internas são duas coisas bem diferentes, e mesmo um simples deslocar-se em câmera lenta foi capaz de atrair a atenção das crianças e também de algumas professoras que assistiam à invasão. Segue a descrição do depoimento de duas profissionais da equipe diretiva, que acompanharam este momento e foram entrevistadas logo após a ação.

\title{
Depoimento professoras: Andrea e Cinara
}

\author{
Eu: Gurias, o que vocês viram? \\ A: O que a gente viu? (pausa). Uma procissão sendo acompanhada por um \\ bando de gente curiosa. \\ Eu: Isso? (eu olhando para a outra) \\ C: Isso. Todo mundo querendo se aproximar, todo mundo querendo ver o que \\ tava acontecendo. E mesmo sem saber o pessoal ficou até o fim, atrás. \\ A: Curioso, e tinha gente filmando para tentar entender o que era. \\ C: Sim, alunos de A30 filmaram tudinho, disseram que filmaram tudinho \\ "filmei tudo, filmei tudo 'sora".
}

Para concluir este artigo, convido o leitor a refletir sobre como estas simples experiências - que em minha hipótese inicial beiravam o risco de não acontecer, tendo em vista a preocupação das/os alunas/ alunos com a sua exposição - provocaram impressões e transformações no olhar de todos os envolvidos e no ambiente do recreio, no momento da ação poética de invasão.

Conforme Schechner (1968), o ambiente constitui o meio em que se vive e só é ambiental se contém uma forma de vida, portanto, supõe sempre o sujeito neste ambiente, caso contrário, é apenas lugar. Se o sujeito não pode interferir no ambiente, então não se torna ambiente. Este interferir torna-se habitar: eu não o visito, ele me habita e eu o habito.

Então, o ambiente é um espaço habitado, que me modifica e o qual eu modifico. Em que dimensão estas modificações e transformações foram possíveis? Fica nesta pesquisa muito difícil de mensurar. O fato é que houve esta interferência e algo entre os/as envolvidos/envolvidas aconteceu. Promoveu-se um maior contato da comunidade com as experimentações cênicas realizadas pelas/pelos alunas/alunos, na tentativa de garantir um espaço de resistência artística com este coletivo. 
A cena contemporânea quer provocar a crise, produzir potência de realização. Não está satisfeita em dar apenas informação, tem preocupação que o sujeito se modifique e que seja capaz de produzir aquilo que modifique sua realidade e a do outro, a realidade de quem vê e de quem faz.

Nesta invenção do caminho, você não sabe quais instrumentos te levam ao foco. Há sempre mais caminhos a percorrer, e estas experiências abrem novas portas. O importante foi encontrar novos espaços de encontro e gerar acontecimentos que nos fazem sair do eixo, que produzam algo que faz o outro sair do lugar para uma ação, para um pensamento, e que apontam para a necessidade e relevância do trabalho de investigação teatral permanente realizado na escola pública.

\section{REFERÊNCIAS}

AGAMBEN, Giorgio. Infância e história: destruição da experiência e origem da história. Belo Horizonte: UFMG, 2005.

ANDRÉ, Carminda Mendes. Apontamentos de uma arte-educadora. São Paulo/Cultura Acadêmica: Universidade Estadual Paulista, 2013.

CARREIRA, André. Ambiente, fluxo e dramaturgias da cidade: materiais do teatro de invasão. Percevejo online: Periódico do Programa de Pós-graduação em Artes Cênicas, jan./jun. 2009.

. Sobre um ator para um teatro que invade a cidade. Moringa: artes do espetáculo. João Pessoa, v. 2, n. 2, jul./dez. 2011.

SCHECHNER, Richard. Seis axiomas para um teatro ambiental. Grupo Experiência Subterrânea. Opholdmareoborder: Relatos de viagem. Experiência Subterrânea/Funarte, Florianópolis, 2012. 